\title{
Karakteristik dan Potensi Enzimatis Bakteri Asal Tanah Sampah Dapur dan Kotoran Ternak sebagai Kandidat Agen Biodegradasi Sampah Organik
}

\section{Taruna Dwi Satwika ${ }^{*}$, Dwiana Muflihah Yulianti², Arif Rahman Hikam ${ }^{3}$}

1,2,3Fakultas Biologi Universitas Jenderal Soedirman Purwokerto

\begin{abstract}
Composting is an alternative for recycling organic waste. Microorganisms that can degrade the components of organic waste are an essential part of composting. Isolation and selection of bacteria with the ability to degrade the elements of organic waste are the first steps to obtain an organic waste degrading agent. This study aimed to determine the characteristics and the enzymatic potential (cellulolytic, amylolytic, and proteolytic) of bacteria isolated from soil, cow dung and kitchen waste as candidates for organic waste degradation agents. The research begins with sampling and isolation of bacteria. The isolates obtained were tested qualitatively for their amylolytic, cellulolytic and proteolytic activities. Furthermore, bacterial isolates were characterized morphologically and biochemically. A total of 30 bacterial isolates were isolated from soil samples, cow dung and kitchen waste. The screening result showed that 6 isolates had amylolytic activity, 7 isolates had cellulolytic activity and 3 isolates had proteolytic activity. These bacterial isolates showed various morphological and biochemical characteristics. In general, soil samples, kitchen waste and cow dung contain potential bacteria as organic waste degrading agents
\end{abstract}

Keywords: Amylolytic bacteria; Cellulolytic bacteria; Organic waste; Proteolytic bacteria

\begin{abstract}
Abstrak
Pengomposan merupakan suatu alternatif untuk mendaur ulang sampah organik. Mikroorganisme unggul yang mampu mendegradasi komponen-komponen penyusun sampah organik merupakan bagian penting dalam pengomposan. Isolasi dan seleksi bakteri dengan kemampuan degradasi komponen-komponen penyusun sampah organik merupakan tahapan awal untuk mendapatkan agen pendegradasi sampah organik. Penelitian ini bertujuan untuk mengetahui karakteristik dan potensi selulolitik, amilolitik, dan proteolitik bakteri asal tanah, kotoran ternak sapi dan sampah dapur sebagai kandidat agen pendegradasi sampah organik. Penelitian diawali dengan pengambilan sampel dan isolasi bakteri. Isolat-isolat yang diperoleh diuji potensi enzimatisnya secara kualitatif, meliputi aktivitas amilolitik, selulolitik, dan proteolitik. Selanjutnya isolat bakteri dengan aktivitas enzimatis dikarakterisasi secara morfologi dan biokimia. Sebanyak 30 isolat bakteri berhasil diisolasi dari sampel tanah, kotoran ternak sapi dan sampah dapur. Hasil penapisan menunjukkan bahwa sebanyak 6 isolat memiliki aktivitas amilolitik, 7 isolat memiliki aktivitas selulolitik dan 3 isolat menunjukkan aktivitas proteolitik. Isolat-isolat bakteri tersebut menunjukkan karakteristik morfologi dan biokimia yang beragam. Secara umum, sampel tanah, sampah dapur dan kotoran sapi mengandung bakteri potensial sebagai agen pendegradasi sampah organik.
\end{abstract}

Kata kunci: Bakteri amilolitik; Bakteri proteolitik; Bakteri selulolitik; Sampah organik,

\footnotetext{
* Corresponding Author: Taruna Dwi Satwita, email : tarunadwisatwika@unsoed.ac.id. Fakultas Biologi Uviversitas Jendral Soedirman, Jl. dr. Suparno 63 Grendeng Purwokerto Utara Kabupaten Banyumas Jawa Tengah, 53122, Indonesia.
}

Copyright (C) 2021 Al-Hayat: Journal of Biology and Apllied Biology 


\section{Pendahuluan}

Pertambahan populasi penduduk menyebabkan produksi sampah organik terus meningkat dan mengakibatkan penumpukkan. Namun, sampah organik umumnya dikumpulkan di tempat pembuangan akhir dan dibiarkan terdekomposisi secara alami sehingga kehilangan potensi untuk didaur ulang (Chiarelotto et al., 2018). Pengomposan berpotensi sebagai alternatif yang dapat dilakukkan untuk mendaur ulang sampah organik. Mikroorganisme telah dikenal sebagai organisme dekomposer karena mampu mendegradasi bahan-bahan organik untuk kerberlangsungan siklus biogeokimia di alam.

Berbagai bakteri telah terbukti memiliki kemampuan untuk mendegradasi komponenkomponen penyusun sampah organik dan mempercepat dekomposisi. Akhtar et al., (2013) melaporkan bahwa pemberian Bacillus sp. AS3 mampu menurunkan rasio $\mathrm{C} / \mathrm{N}$, residu selulosa, dan kandungan karbon lebih tinggi dibanding kontrol setelah 90 hari dekomposisi sampah dedaunan. Kombinasi berbagai jenis mikroorganisme juga dilaporkan mampu mempercepat permulaan proses dekomposisi, meningkatkan laju humifikasi, memperpendek waktu pematangan kompos, dan meningkatkan detoksifikasi material awal (Echeverria et al., 2011).

Isolasi dan seleksi bakteri dengan kemampuan degradasi komponen-komponen penyusun sampah organik merupakan tahapan awal untuk mendapatkan isolat bakteri agen dekomposer unggul. Berbagai isolat bakteri potensial pendegradasi sampah telah dilaporkan berhasil diisolasi dari berbagai sampel, antara lain sampah perkotaan (Maki et al., 2012), tanah hutan tropis (Woo et al., 2014), tanah sekitar tempat pembuangan akhir (TPA) (Rashid et al., 2017), dan kotoran sapi (Akhtar et al., 2013). Namun, penelitian yang telah dilaporkan masih terbatas pada potensi selulolitik sehingga hanya dapat digunakan untuk dekomposisi serasah daun, sisa hasil pertanian dan kertas bekas.

Isolat bakteri pendegradasi sampah organik harus memiliki kemampuan dalam mendegradasi komponen- komponen yang terkandung dalam sampah organik. Komponenkomponen penyusun sampah organik yang menjadi target biodegradasi, yaitu selulosa (Akhtar et al., 2013; Jabir \& Jabir, 2016), amilum (Krishna \& Mohan, 2017), dan protein (Krishna \& Mohan, 2017; Mazzucotelli et al., 2013), sehingga penelitian ini dilakukan untuk menguji aktivitas bakteri dalam mendegradasi selulosa, amilosa dan protein. Tujuan dari penelitian ini adalah untuk mengetahui karakteristik dan potensi selulolitik, amilolitik, dan proteolitik bakteri asal tanah, kotoran ternak sapi dan sampah dapur sebagai kandidat agen pendegradasi sampah organik.

\section{Metode Penelitian}

\section{Pengambilan Sampel dan Isolasi Bakteri}

Isolat bakteri diperoleh dari sampel tanah, sampah dapur dan kotoran sapi. Sampel tanah diperoleh dari halaman bagian selatan Fakultas Biologi Universitas Jenderal Soedirman, sampel sampah dapur diambil dari tempat pembuangan sampah kantin Fakultas Biologi, dan sampel kotoran ternak diambil dari Experimental Farm Fakultas Peternakan Universitas Jenderal Soedirman.

Sebanyak 10 gram masing-masing sampel dimasukkan ke dalam $90 \mathrm{~mL}$ akuades steril dan dishaker selama 1 jam pada kecepatan $150 \mathrm{rpm}$. Suspensi yang dihasilkan kemudian diencerkan secara bertingkat menggunakan akuades steril dan sebanyak $100 \mu \mathrm{l}$ suspensi dari pengenceran $10^{-5}, 10^{-6}$ dan $10^{-7}$ diinokulasikan secara duplo mengguakan metode spread plate pada media Nutrient Agar (NA) (Oxoid) di cawan petri steril. Inkubasi media NA dilakukan selama 48 jam pada suhu ruangan. Koloni bakteri yang menunjukkan karakter morfologi berbeda dimurnikan dengan metode gores kuadran.

\section{Uji Potensi Enzimatis secara Kualitatif}

\section{Uji Selulolitik}

Isolat bakteri ditumbuhkan pada medium carboxymethyl cellulose (CMC) Agar (Islam \& Roy, 2018) secara goresan spot. Media CMC diinkubasi selama 24 jam pada suhu ruang. Kemudian, Congo-red 0,1\% (w/v) dituangkan ke medium hingga seluruh permukaan medium terendam. Perendaman dilakukan selama 20 
menit. Kemudian medium dibilas dengan larutan $\mathrm{NaCl} 1 \mathrm{M}$. Diameter $(\mathrm{mm})$ zona jernih dan diameter koloni diukur. Aktivitas degradasi selulosa ditunjukkan dengan nilai indeks selulolitik. Indeks selulolitik diperoleh dari rasio antara diameter zona jernih dengan diameter koloni.

\section{Uji Amilolitik}

Isolat bakteri ditumbuhkan pada medium starch agar (SA) (Lal \& Cheeptham, 2012) secara goresan spot. Media SA diinkubasi selama 24 jam pada suhu ruang. Kemudian larutan Lugol's iodine dituangkan ke medium. Diameter (mm) zona jernih dan diameter koloni diukur. Aktivitas degradasi amilum ditunjukkan dengan nilai indeks amilolitik. Indeks amilolitik diperoleh dari rasio antara diameter zona jernih dengan diameter koloni.

\section{Uji Proteolitik}

Isolat bakteri ditumbuhkan pada medium skim milk agar (SMA) (HiMedia) secara goresan spot. Inkubasi dilakukan selama 24 jam pada suhu ruang. Terbentuknya zona jernih disekitar koloni diamati. Diameter ( $\mathrm{mm}$ ) zona jernih dan diameter koloni diukur. Aktivitas degradasi protein ditunjukkan dengan nilai indeks proteolitik. Indeks proteolitik diperoleh dari rasio antara diameter zona jernih dengan diameter koloni.

\section{Karakterisasi Isolat Bakteri}

\section{Karakterisasi Morfologi}

Isolat-isolat yang memiliki potensi untuk mendegradasi sampah organik dikarakterisasi secara morfologis. Isolat bakteri murni diamati karakter fenotipiknya, yaitu warna koloni, bentuk koloni, tepi koloni, elevasi koloni dan karakteristik optik. Isolat juga dikarakterisasi secara mikroskopis menggunakan teknik pewarnaan Gram untuk melihat bentuk sel dan sifat Gram.

\section{Uji Katalase}

Sebanyak 1 ose isolat bakteri diulaskan di atas object glass menggunakan jarum ose. Reagen $\mathrm{H}_{2} \mathrm{O}_{2}$ kemudian diteteskan di atas ulasan isolat bakteri. Interpretasi positif ditandai dengan tidak adanya gelembung gas di atas ulasan isolat.

\section{Uji Oksidase}

Isolat bakteri diambil sebanyak 1 ose dan diulaskan pada kertas saring. Kertas saring ditetesi dengan 1-2 tetes reagen (tetramethyl- $D$ phenylenediamine dihydrochloride). Interpretasi positif ditandai dengan adanya perubahan warna menjadi biru marun pada ulasan bakteri.

\section{Hasil Penelitian dan Pembahasan}

Sebanyak 30 isolat bakteri dengan karakter morfologi koloni berbeda berhasil diisolasi dari sampel tanah, sampah dapur dan kotoran sapi. Seluruh isolat diskrining pada medium CMC agar, SA, dan SMA untuk menguji aktivitas selulolitik, amilolitik, dan proteolitik secara kualitatif. Pengujian secara kualitatif merupakan tahapan awal dalam melihat potensi enzimatis isolat bakteri untuk mendegradasi komponen yang terkandung dalam sampah organik.

$\begin{array}{llllll}\text { Sebanyak } & 6 & \text { dari } & 30 & (20 \%) & \text { isolat }\end{array}$ menunjukkan aktivitas amilolitik, yaitu Tn6, Tn8, Tn9, Tn11, Tn13, dan SD10. Hal ini ditunjukkan dengan zona jernih disekitar koloni (Gambar 1a). Zona jernih / transparan di sekitar koloni bakteri dengan latar belakang kebiruan mengindikasikan aktivitas hidrolisis amilum oleh bakteri (Awan et al., 2018). Reagen iodin yang digunakan sebagai indikator akan menghasilkan warna kebiruan apabila membentuk kompleks dengan polimer karbohidrat yang terdapat pada medium pertumbuhan bakteri. Terbentuknya zona jernih menunjukkan bahwa enzim amilase ekstraseluler bakteri telah mendegradasi amilum menjadi gula sederhana.

$\begin{array}{llllll}\text { Sebanyak } & 7 & \text { dari } & 30 & (23 \%) & \text { isolat }\end{array}$ menunjukkan aktivitas selulolitik, yaitu Tn6, Tn13, SD1, SD5, KS1, KS3, dan KS4. Hal ini ditunjukkan dengan zona jernih disekitar koloni (Gambar 1b). Zona jernih terbentuk karena kandungan CMC dalam medium telah didegradasi oleh enzim selulase ekstraseluler bakteri menjadi molekul yang lebih sederhana. Reagen Congo-red hanya dapat berinteraksi dengan $\beta$-(1-4)-D-glukan dalam CMC sehingga membentuk warna merah. 
Gambar 1

Aktivitas Enzimatis Isolat Bakteri. A. Amilolitik; B. Selulolitik; C. Proteolitik.

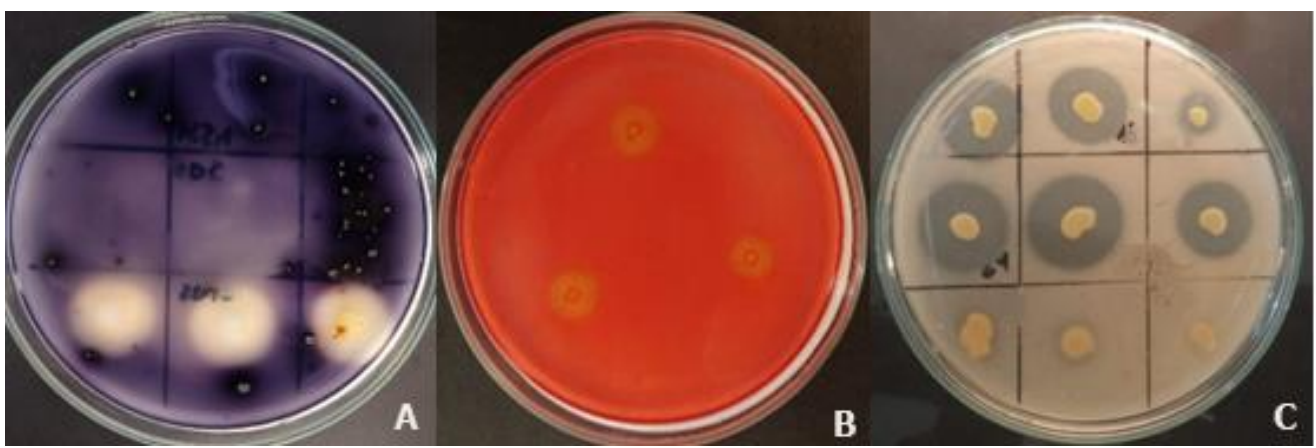

Tabel 1

Jumlah Isolat dan Hasil Skrining Aktivitas Amilolitik, Selulolitik, dan Proteolitik

\begin{tabular}{lcccc}
\hline \multirow{2}{*}{ Sampel } & \multirow{2}{*}{ Jumlah Isolat } & \multicolumn{3}{c}{ Penapisan } \\
\cline { 3 - 5 } & & Amilolitik & Selulolitik & Proteolitik \\
\hline Tanah & 14 & 5 & 2 & 3 \\
Kotoran Sapi & 6 & 0 & 3 & 0 \\
Sampah Dapur & 10 & 1 & 2 & 0 \\
\hline \multicolumn{1}{c}{ Total } & 41 & 6 & 7 & 3 \\
\hline
\end{tabular}

Bakteri proteolitik tidak ditemukan pada sampel sampah dapur. Hal ini diduga karena sampah dapur yang kami ambil didominasi oleh sisa makanan dari tanaman seperti nasi dan sayuran. Oleh karena itu, bakteri yang terpicu pertumbuhannya adalah bakteri selulolitik dan amilolitik. Beberapa penelitian telah melaporkan keberadaan bakteri selulolitik dan amilolitik pada sampah rumah tangga (Hasan et al., 2017; Maki et al., 2012). Hal menarik ditunjukkan pada sampel kotoran sapi. Hanya bakteri selulolitik yang terdeteksi pada sampel tersebut. Dominasi bakteri selulolitik kemungkinan terjadi karena kandungan selulosa yang masih dominan pada kotoran sapi. Keberadaan bakteri selulolitik pada kotoran sapi telah banyak dilaporkan (Akhtar et al., 2013; Chahar \& Prakash, 2017).
Aktivitas selulolitik, amilolitik, dan proteolitik ditunjukkan pada Tabel 2. Indeks selulolitik, amilolitik, dan proteolitik secara berurutan berkisar dari 1,14-2,35; 0,422,72; dan 1,26-1,99 (Tabel 2). Indeks selulolitik, amilolitik dan proteolitik tertinggi secara berurutan ditunjukkan oleh isolat KS4, Tn13, dan Tn24. Nilai indeks selulolitik, amilolitik, dan proteolitik lebih dari 1 menunjukkan bahwa diameter zona jernih lebih besar dari diameter koloni. Hal ini menunjukkan bahwa isolat bakteri menghasilkan enzim ekstraseluler.

Sebanyak 2 isolat menunjukkan aktivitas selulolitik dan amilolitik, yaitu isolat Tn6 dan Tn13. Kedua isolat tersebut diisolasi dari tanah. Hasil yang sama ditunjukkan oleh penelitian Sarkar et al., (2011) yang berhasil memperoleh isolat bakteri asal tanah dengan kemampuan selulolitik dan amilolitik. 
Tabel 1

Jumlah Isolat dan Hasil Skrining Aktivitas Amilolitik, Selulolitik, dan Proteolitik

\begin{tabular}{ccccc}
\hline Kode Isolat & Asal Isolat & Indeks Selulolitik & Indeks Amilolitik & Indeks Proteolitik \\
\hline Tn2 & Tanah & - & - & $1,26 \pm 0,07$ \\
Tn3 & Tanah & - & - & $1,52 \pm 0,15$ \\
Tn6 & Tanah & $2,30 \pm 0,26$ & $2,12 \pm 0,11$ & - \\
Tn8 & Tanah & - & $1,35 \pm 0,08$ & - \\
Tn9 & Tanah & - & $1,92 \pm 0,56$ & - \\
Tn11 & Tanah & - & $0,42 \pm 0,72$ & - \\
Tn13 & Tanah & $1,21 \pm 0,14$ & $3,43 \pm 0,36$ & - \\
Tn24 & Tanah & - & - & $1,99 \pm 0,34$ \\
SD1 & Sampah Dapur & $2,05 \pm 0,27$ & - & - \\
SD5 & Sampah Dapur & $1,14 \pm 0,03$ & - & - \\
SD10 & Sampah Dapur & - & $2,53 \pm 0,09$ & - \\
KS1 & Kotoran Sapi & $1,24 \pm 0,05$ & - & - \\
KS3 & Kotoran Sapi & $1,71 \pm 0,29$ & - & - \\
KS4 & Kotoran Sapi & $2,35 \pm 0,22$ & - & - \\
\hline
\end{tabular}

\section{Tabel 2}

Jumlah Isolat dan Hasil Skrining Aktivitas Amilolitik, Selulolitik, dan Proteolitik

\begin{tabular}{|c|c|c|c|c|c|c|c|c|c|}
\hline \multirow{2}{*}{$\begin{array}{l}\text { Kode } \\
\text { Isolat }\end{array}$} & \multicolumn{5}{|c|}{ Morfologi Koloni } & \multicolumn{2}{|c|}{ Morfologi Sel } & \multirow[t]{2}{*}{ Oksidase } & \multirow[t]{2}{*}{ Katalase } \\
\hline & Bentuk & Warna & Elevasi & Margin & $\begin{array}{c}\text { Karakter } \\
\text { optik }\end{array}$ & Bentuk & Gram & & \\
\hline $\operatorname{Tn} 2$ & Sirkuler & Putih & Raised & Entire & Opaque & Coccus & + & - & + \\
\hline $\operatorname{Tn} 3$ & Sirkuler & Kuning & Raised & Entire & Opaque & Coccus & + & + & + \\
\hline $\operatorname{Tn} 6$ & Sirkuler & Krem & Raised & Entire & Opaque & Coccus & + & + & + \\
\hline Tn8 & Irregular & Orange & Raised & Lobate & Translucent & Coccus & + & + & + \\
\hline Tn9 & Irregular & Krem & Flat & Undulate & Opaque & Coccus & + & + & + \\
\hline $\operatorname{Tn} 11$ & Sirkuler & Bening & Raised & Entire & Translucent & Coccus & + & + & + \\
\hline $\operatorname{Tn} 13$ & Sirkuler & Putih & Raised & Entire & Translucent & Basil & + & + & + \\
\hline $\operatorname{Tn} 24$ & Sirkuler & Kuning & Raised & Entire & Opaque & Coccus & + & + & + \\
\hline SD1 & Sirkuler & Krem & Flat & Entire & Opaque & Basil & - & + & + \\
\hline SD5 & Irregular & Putih & Flat & Undulate & Translucent & Basil & + & + & + \\
\hline SD10 & Sirkuler & Krem & Raised & Entire & Opaque & Coccus & + & + & + \\
\hline KS1 & Sirkuler & Krem & Flat & Entire & Opaque & Basil & - & + & + \\
\hline KS3 & Sirkuler & Krem & Flat & Entire & Translucent & Basil & + & + & + \\
\hline KS4 & Irregular & Krem & Flat & Lobate & Opaque & Basil & - & - & + \\
\hline
\end{tabular}


Isolat bakteri selulolitik, amilolitik, dan proteolitik yang diperoleh menunjukkan keragaman karakter baik dari segi morfologi koloni maupun morfologi sel (Tabel 3). Berdasarkan karakter morfologi sel, 8 isolat merupakan bakteri gram positif coccus, 3 isolat gram positif basil dan 3 isolat gram negatif basil. Isolat-isolat bakteri dengan kemampuan selulolitik, proteolitik, dan amilolitik yang diperoleh didominasi oleh bakteri Gram positif. Beberapa penelitian sebelumnya mendukung hasil tersebut. Sebanyak 7 dari 8 isolat bakteri amilolitik yang diisolasi dari tanah dan sampah merupakan bakteri Gram positif (Saha et al., 2019).

Sebanyak 12 isolat menunjukkan sifat oksidase positif dan katalase positif, sedangkan 2 isolat menunjukkan oksidase negatif dan katalase positif (Tabel 3). Bakteri aerob dan fakultatif anaerob umumnya mampu menghasilkan enzim katalase (Madigan et al., 2015). Enzim katalase berperan dalam mendegradasi hidrogen peroksida $\left(\mathrm{H}_{2} \mathrm{O}_{2}\right)$ yang bersifat toksik menjadi air dan oksigen. Uji oksidase merupakan uji biokimia untuk mendeteksi adanya sitokrom oksidase. Sitokrom oksidase merupakan enzim yang berperan dalam rantai transport elektron pada respirasi aerobik. Hasil uji katalase dan oksidase menunjukkan bahwa 12 isolat merupakan bakteri obligat aerob, sedangkan 2 isolat diduga merupakan fakultatif anaerob. Hasil ini sejalan dengan Akhtar et al. (2013) yang mendapatkan 3 isolat dengan aktivitas katalase dan oksidase. Metode isolasi yang digunakan mempengaruhi karakteristik isolat yang diperoleh. Inkubasi medium pertumbuhan pada saat isolasi pada penelitian ini dilakukan dalam keadaan aerobik sehingga mendukung pertumbuhan bakteri aerob maupun fakultatif anaerob. Sedangkan bakteri obligat anaerob akan terhambat.

Isolat-isolat bakteri dengan aktivitas selulolitik, amilolitik, dan proteolitik yang diperoleh membuktikan bahwa tanah, sampah dapur dan kotoran sapi merupakan sumber bakteri potensial sebagai pendegradasi sampah organik. Isolat-isolat bakteri yang diperoleh masih perlu diuji lebih lanjut aktivitas enzimatisnya secara kuantitatif dan kemampuannya dalam mendegradasi sampah organik. Selain itu, isolat bakteri yang diperoleh belum diketahui identitas spesiesnya sehingga perlu dilakukan karakterisasi biokimia dan molekuler untuk mengetahui identitasnya.

\section{Simpulan dan Saran}

\section{Simpulan}

Sebanyak 30 isolat bakteri berhasil diisolasi dari tanah, sampah dapur dan kotoran sapi. Dari 30 isolat tersebut, 7 isolat menunjukkan aktivitas selulolitik, 6 isolat menunjukkan aktivitas amilolitik, dan 3 isolat menunjukkan aktivitas proteolitik. Berdasarkan sifat morfologi dan biokimia, isolat-isolat bakteri yang memiliki aktivitas selulolitik, amilolitik, dan proteolitik menunjukkan karakteristik yang berbedabeda. Isolat-isolat bakteri dengan aktivitas selulolitik, amilolitik dan proteolitik berpotensi sebagai kandidat agen pendegradasi sampah organik.

\section{Ucapan Terima Kasih}

Ucapan terima kasih penulis sampaikan kepada Lembaga Penelitian dan Pengabdian kepada Masyarakat Universitas Jenderal Soedirman atas dukungan berupa dana penelitian yang bersumber dari DIPA UNSOED Tahun Anggaran 2020. 


\section{Daftar Pustaka}

Akhtar, N., Sharma, A., Deka, D., Jawed, M., Goyal, D., \& Goyal, A. (2013). Characterization of cellulase producing Bacillus sp. for effective degradation of leaf litter biomass. Environmental Progress and Sustainable Energy. https://doi.org/10.1002/ep.11726

Awan, K., Jabeen, F., Manzoor, M., \& Qazi, J. I. (2018). Potential of thermophilic amylolytic bacteria for growth in unconventional media: Potato peels. Journal of Food Process Engineering, 41(1), 1-7. https://doi.org/10.1111/jfpe.12635

Chahar, P. J., \& Prakash, A. (2017). Isolation and Molecular Characterization of Cellulolytic Microbes From Cow Dung. 6(1), 1-4.

Chiarelotto, M., Bottin, W. C., Spicker, C. E., Duarte, S. S., Chiarelotto, M., \& Bortoli, M.M. (2018). Composting of household organic waste: effect on control parameters and final compound quality.Revista Agro@MbienteOn-Line, 12(4), 272. https://doi.org/10.18227/19828470ragro.v12i4.5126

Echeverria, M. C., Cardelli, R., Bedini, S., Agnolucci, M., Cristani, C., Saviozzi, A., \& Nuti, M. (2011). Composting Wet Olive Husks with a Starter Based on OilDepleted Husks Enhances Compost Humification. Compost Science and Utilization, 19(3), 182-188. https://doi.org/10.1080/1065657X.2 011.10736998

Hasan, M. M., Marzan, L. W., Hosna, A., Hakim, A., \& Azad, A. K. (2017). Optimization of some fermentation conditions for the production of extracellular amylases by using Chryseobacterium and Bacillus isolates from organic kitchen wastes. Journal of Genetic Engineering and Biotechnology, 15(1), 59-68. https://doi.org/10.1016/j.jgeb.2017.0 2.009

Islam, F., \& Roy, N. (2018). Screening, purification and characterization of cellulase from cellulase producing bacteria in molasses. BMC Research Notes.

https://doi.org/10.1186/s13104018-3558-4

Jabir, D. M., \& Jabir, M. M. (2016). A study of biodegradation of paper wastes by using bacteria isolated from the soil. Asian Journal of Microbiology, Biotechnology and Environmental Sciences, 18(3), 777-780. https://doi.org/10.13140/RG.2.2.336 01.97124

Jini, R., Swapna, H. C., Rai, A. K., Vrinda, R., Halami, P. M., Sachindra, N. M., \& Bhaskar, N. (2011). Isolation and characterization of potential lactic acid bacteria (LAB) from freshwater fish processing wastes for application in fermentative utilisation of fish processing waste. Brazilian Journal of Microbiology.

https://doi.org/10.1590/S151783822011000400039

Krishna, M. P., \& Mohan, M. (2017). Litter decomposition in forest ecosystems: a review. Energy, Ecology and Environment, 2(4), 236-249. https://doi.org/10.1007/s40974017-0064-9

Lal, A., \& Cheeptham, N. (2012). Starch agar protocol. American Society for Microbiology.

Liang, Y. L., Zhang, Z., Wu, M., Wu, Y., \& Feng, J. X. (2014). Isolation, screening, and identification of cellulolytic bacteria from natural reserves in the subtropical region of China and optimization of cellulase production by Paenibacillus terrae ME27-1. BioMed Research International. https://doi.org/10.1155/2014/5124 
97

Madigan, M., Martinko, J. M., Bender, K. S., Buckley, D. H., \& Stahl, D. A. (2015). Brock: Biology of the Microorganisms. In Journal of Chemical Information and Modeling.

Maki, M. L., Idrees, A., Leung, K. T., \& Qin, W. (2012). Newly isolated and characterized bacteria with great application potential for decomposition of lignocellulosic biomass. Journal of Molecular Microbiology and Biotechnology, 22(3), 156-166. https://doi.org/10.1159/000341107

Mazzucotelli, C. A., Ponce, A. G., Kotlar, C. E., \& Moreira, M. del R. (2013). Isolation and characterization of bacterial strains with a hydrolytic profile with potential use in bioconversion of agroindustial by-products and waste. Food Science and Technology, 33(2), 295-303. https://doi.org/10.1590/S010120612013005000038

Mishra, S., \& Behera, N. (2008). Amylase activity of a starch degrading bacteria isolated from soil receiving kitchen wastes. African Journal of Biotechnology, 7(18), 3326-3331. https://doi.org/10.5897/AJB08.582

Rashid, G. M. M., Durán-Peña, M. J., Rahmanpour, R., Sapsford, D., \& Bugg, T. D. H. (2017). Delignification and enhanced gas release from soil containing lignocellulose by treatment with bacterial lignin degraders. Journal of Applied Microbiology. https://doi.org/10.1111/jam.13470

Saha, M. L., Islam, K. N., Akter, T., Rahman, I. A., Islam, T., \& Khan, T. (2019). Isolation and identification of amylolytic bacteria from garbage and garden soil. Bangladesh Journal of Botany. https://doi.org/10.3329/BJB.V48I3.4 7915

Sarkar, P., Meghvanshi, M., \& Singh, R. (2011). Microbial Consortium: A New Approach in Effective Degradation of Organic Kitchen Wastes. International Journal of Environmental Science and Development. https://doi.org/10.7763/ijesd.2011.v 2.118

Silaban, S., Marika, D. B., \& Simorangkir, M. (2020). Isolation and characterization of amylase-producing amylolytic bacteria from rice soil samples. Journal of Physics: Conference Series, 1485(1). https://doi.org/10.1088/17426596/1485/1/012006

Soundra Josephine, F., S, R. V, Devi, N., Babu Ganapa, S., \& G, S. K. (2012). Isolation, production and characterization of protease from Bacillus Sp isolated from soil sample. Journal of Microbiology and Biotechnology Research Scholars Research Library J. Microbiol. Biotech. Res.

Utomo, M. A. P. and S. M. (2014). Bakteri Tanah Pendegradasi Bahan Organik. $3(2), 80-83$.

Woo, H. L., Hazen, T. C., Simmons, B. A., \& DeAngelis, K. M. (2014). Enzyme activities of aerobic lignocellulolytic bacteria isolated from wet tropical forest soils. Systematic and Applied Microbiology, 37(1), 60-67. https://doi.org/10.1016/j.syapm.201 3.10 .001 